\title{
PENGUATAN WAWASAN KEBANGSAAN DAN MODERASI ISLAM UNTUK GENERASI MILLENIAL
}

\author{
Rohmatul Faizah \\ Universitas Pembangunan Nasional Veteran Jawa Timur \\ rohmatulfaizah.ih@upnjatim.ac.id
}

\begin{abstract}
Abstrak
The spirit of globalisation had cut out the big world to the narrow world and its today's impact could reduce the nationalism for most of people, especially for college students. This study was qualitative study which was strengthened by the field study. The data collection technique was documentation, observation, and interview. The followings were four results from the analysed data: The nationalism knowledge programs and Islamic moderation were implemented in some subjects. They were, nationalism, widya mwat yasa, civic education, Pancasila, Islamic religion, and sports. The implementation of the nationalism knowledge and Islamic moderation reflected to some things. They were the students who were tolerant (tasamuh), moderate (tawasuth), balance (tawazun), amar ma'ruf nahi munkar.
\end{abstract}

Keywords: Nationality Insight; Islamic Moderation; UPNV Yogyakarta

\begin{abstract}
Semangat globalisasi telah memangkas bola dunia yang luas menjadi sempit dan pengaruh globalisasi di era sekarang juga dapat mengikis rasa cinta tanah air bagi sebagian besar individu, khususnya di kalangan mahasiswa. Penelitian ini merupakan penelitian kualitatif yang diperkuat dengan penelitian lapangan. Teknik pengumpulan data penelitian ini adalah dokumentasi, observasi dan wawancara. Dari hasil penelitian yang dilakukan terdapat empat temuan sebagai berikut: Program-program penguatan wawasan kebangsaan dan moderasi Islam ini diimplementasikan dalam beberapa mata kuliah, diantaranya, bela negara dan widya mwat yasa, kewarganegaraan, pancasila, agama Islam, dan olah raga. Penerapan wawasan kebangsaan dan moderasi Islam ini tercermin dalam beberapa hal, diantaranya mahasiswa memiliki rasa tasamuh (toleran), tawasuth (moderat), tawazun (seimbang), amar ma'ruf nahi munkar.
\end{abstract}

Kata Kunci: Wawasan Kebangsaan; Moderasi Islam; UPNV Yogyakarta 


\section{PENDAHULUAN}

Era teknologi informasi dan komunikasi yang datang tidak terelakkan ini telah menyisakan sebuah tantangan yang harus kita hadapi bersama. Tantangan tersebut tak lain berupa "perubahan" dalam semua lini dan aspek kehidupan. ${ }^{1}$ Semangat globalisasi telah memangkas bola dunia yang luas menjadi sempit. Sebagai dampaknya, laju informasi dan sistem komunikasi bukan saja sulit disaring apalagi dibendung, tetapi sekaligus mengaburkan nilai-nilai kemanusiaan dalam pranata kehidupan umat beragama sehari-hari.

Selain itu pengaruh globalisasi di era sekarang juga dapat mengikis rasa cinta tanah air bagi sebagian besar individu, ${ }^{2}$ khususnya di kalangan mahasiswa. Kita memang tidak diperbolehkan menghindar dari globalisasi, karena kita akan menjadi bangsa yang tertinggal dan kurang pergaulan. Padahal sejatinya globalisasi bisa membawa seseorang untuk bersaing di kancah internasional. Tergantung bagaimana individu menyikapi pengaruh globalisasi tersebut.

Globalisasi menyediakan seluruh fasilitas yang dibutuhkan manusia, negatif maupun positif. ${ }^{3}$ Kompetensi, integrasi, dan kerja sama adalah dampak positif globalisasi. Lahirnya generasi instan (generasi now atau generasi sekarang, langsung bisa menikmati keinginan tanpa proses perjuangan dan kerja keras), dekadensi moral, dan konsumerisme, bahkan permisifisme adalah sebagian dari dampak negatif dari globalisasi.

\footnotetext{
${ }^{1}$ Abu Yasid, Islam Moderat, (Jakarta: Penerbit Erlangga, 2014), hlm. 1.

${ }^{2}$ Partini, National Character Building in the Third Millenium Era: A Challenge. Southeast Asian Journal of Social and Political Issues. Vol. 1. No. 2. Maret 2012. hlm. 23.

${ }^{3}$ Suyadi, Strategi Pembelajaran Pendidikan Karakter, (Bandung: PT Remaja Rosdakarya, 2013), hlm. 15.
} 
Efek dari globalisasi sudah menyebar ke seluruh penjuru dunia, bahkan sampai daerah terpencil sekalipun, masuk ke rumah-rumah, membombardir pertahan moral dan agama, sekuat apapun dipertahankan. Televisi, internet, koran, handphone, dan lain-lain adalah media informasi dan komunikasi yang berjalan dengan cepat, menggulung sekat-sekat tradisional yang selama ini dipegang kuat-kuat. Moralitas menjadi longgar. Sesuatu yang dahulu dianggap tabu, sekarang menjadi biasa-biasa. Tata cara bergaul dengan lawan jenis, sopan santun kepada orang yang lebih tua, cara berpakaian, tempat hiburan dan tempat karaoke menjadi tempat favorit. Narkoba sudah merajalela baik di kalangan pelajar mahasiswa maupun masyarakat awam pada umumnya. Semua ini dikarenakan pengaruh globalisasi yang dengan mudahnya mendapatkan apapun yang diinginkan manusia. ${ }^{4}$

Indonesia akan mengalami apa yang disebut dengan "bonus demografi” di sekitar tahun 2025-2030. Berdasarkan prediksi Badan Kependudukan dan Keluarga Berencana Nasional (BKKBN), pada tahun-tahun tersebut, $70 \%$ warga Indonesia berada di usia produktif, yakni antara usia 15 hingga 64 tahun. Hanya sekitar $30 \%$ yang berusia tidak produktif, yakni mulai usia 14 tahun ke bawah dan 65 tahun ke atas. $^{5}$

Bonus demografi tersebut dapat meningkatkan jumlah anak muda atau yang sekarang banyak disebut dengan generasi millenial. Gaya hidup anak muda millenial akan memiliki pengaruh yang besar terhadap berbagai aspek kehidupan, baik secara personal maupun publik, baik dari sisi sosial, budaya, hingga ekonomi, politik bahkan hingga agama. Anak

${ }^{4}$ Dadan Sumara, Kenakalan Remaja Dan Penanganannya, Jurnal Penelitian \& PPM ISSN: 2442-448X Vol 4, No: 2, 2017, hlm. $129-389$.

${ }^{5}$ Agus Iswanto, Membaca Kecenderungan Pemikiran Islam Generasi Millenial Indonesia, Jurnal Multikultural dan Multireligius Vol. 17. No. 1. Juni 2018. h. 1. 
muda Muslim memiliki posisi yang strategis. Muslim millenial dapat mengangkat citra Islam Indonesia agar menjadi rujukan dunia dalam mewujudkan masyarakat yang damai dan berkeadaban. Namun, faktanya sekarang ini banyak narasi kebencian dan bahkan aksi kekerasan hingga teror dilakukan oleh anak-anak muda.

Generasi muda atau millenial menjadi tolak ukur terhadap nasib dan masa depan dari umat atau bangsa tersebut. ${ }^{6}$ Jika ingin melihat kekuatan dan ketahanan suatu umat dan bangsa, maka lihatlah dari kualitas generasi muda yang mereka miliki. Jika generasi muda mereka baik, maka pastilah kekuatan mereka juga baik dan sulit untuk dipengaruhi oleh ideologi atau pemikiran bangsa atau umat lainnya. Namun sebaliknya, jika generasi muda suatu bangsa atau umat buruk, maka dapat dipastikan mereka sangat rentan dengan kehancuran dan mudah untuk dipengaruhi oleh ideologi bangsa atau umat lain.

Hilangnya konsep pemahaman nilai Islam menjadi salah satu inti permasalahan yang akan membawa Islam ke gerbang kehancuran. Pemahaman tentang konsep moderasi Islam akan menjadi penjaga keimanan dan kekuatan dari pada pemuda selaku generasi penerus Islam dan akan memberikan alasan yang kuat mengapa mereka mempertahankan keislaman.

Indonesia dengan kebhinekaan dan kebesaran nusantaranya kini kesulitan menghadapi gejolak-gejolak yang terjadi di masyarakat. Indonesia ibarat tidak memiliki landasan nilai-nilai kearifan lokal untuk menyelesaikan berbagai masalah. Indikator yang dapat terlihat dari uraian tersebut adalah pemuda sekarang ini seakan-akan terombangambing oleh arus globalisasi dan cenderung melupakan nilai luhur

${ }^{6}$ J. Rosalina Kristyanti, dkk, Peluang dan Tantangan Pendidikan Abad 21, (Jakarta: Sampoerna University, 2012), hlm. 11. 
kebudayaan bangsa yang berimbas terjadinya degradasi karakter pada generasi muda ditandai dengan menurunnya rasa nasionalisme.

Arus globalisasi juga telah membuka peluang bagi berkembangnya organisasi Islam radikal. Eksistensi organisasi Islam radikal sesungguhnya merupakan ancaman bagi masa depan Islam Indonesia. ${ }^{7}$ Islam Indonesia merupakan Islam yang dikenal dengan karakter ramah, toleran, dan nasionalis. Dinamika dan pertumbuhan Islam di Indonesia selama ratusan tahun menunjukkan bahwa Islam toleran dan damai dapat hidup menyatu dengan masyarakat Indonesia. Islam radikal sesungguhnya merupakan karakteristik Islam yang tidak memiliki harapan hidup di masa depan. Hal ini disebabkan oleh salah satunya penolakan yang dilakukan oleh kelompok Islam radikal terhadap kearifan nilai-nilai budaya Indonesia.

Pendidikan agama Islam menekankan pada kemampuan memahami keimanan dan keyakinan Islam sehingga memiliki keyakinan yang kokoh dan mampu mempertahankan keyakinannya serta menghayati dan mengamalkan nilai-nilai ajaran Islam. Terkait pendidikan, mata kuliah agama Islam memiliki kontribusi dalam memberikan motivasi kepada mahasiswa untuk mempelajari dan mempraktikkan akidahnya dalam bentuk pembiasaan untuk melakukan akhlak terpuji dan menginternalisasikan nilai-nilai luhur seperti nilai-nilai keutamaan, nilai kerja keras, nilai cinta tanah air, nilai demokrasi, nilai kesatuan, menghidupi nilai-nilai moral, dan nilai-nilai kemanusiaan dalam kehidupan sehari-hari.

Selain itu mata kuliah pendidikan agama Islam juga mengadakan kegiatan-kegiatan praktikum yang berkaitan dengan moderasi Islam.

\footnotetext{
${ }^{7}$ Wasid Mansyur, Menegaskan Islam Indonesia, Belajar dari Tradisi Pesantren dan NU, (Surabaya: Pustaka Idea, 2014), hlm. 39.
} 
Definisi moderasi Islam atau dalam bahasa Arab disebut wasatiyyah, sebagaimana yang diungkapkan yusuf al Qardhawi dalam bukunya terkait wasațiyyah yaitu upaya menjaga keseimbangan antara dua sisi yang berlawanan agar jangan sampai salah satu mendominasi dan menegasikan yang lain (Yusuf Al-Qardawi:1983). ${ }^{8}$ Dari penjelasan di atas bisa kita simpulkan tujuan mempelajari moderasi Islam adalah agar mahasiswa mampu memahami Islam secara kaffah. Sehingga para mahasiswa mampu memahami dengan betul makna Islam yang sesungguhnya, Islam yang tidak menyukai perpecahan bahkan Islam adalah agama yang sangat cinta pada perdamaian.

Universitas Pembangunan Nasional (UPN) Veteran Yogyakarta, merupakan kampus bela negara ${ }^{9}$, kampus ini memiliki mata kuliah wajib bela negara dan widya mwat yasa (WIMAYA), dari mata kuliah ini mahasiswa belajar tentang materi-materi wawasan kebangsaan dan bagaimana pengaplikasiannya dalam kehidupan sehari-hari, bagaimana peran mahasiswa dalam mewujudkan negara Indonesia yang damai, sejahtera tanpa adanya perpecahan. Selain mata kuliah bela negara di UPN Veteran Yogyakarta ini juga terdapat mata kuliah agama Islam, yang mana di dalam silabusnya juga dikolaborasikan antara agama dan kebangsaan, agar terhindar dari yang namanya radikalisme dan tindakantindakan yang melanggar aturan seperti korupsi dan yang lainnya. Sehingga menurut peneliti kampus ini sangat sesuai jika digunakan sebagai objek penelitian.

\footnotetext{
${ }^{8}$ Yusuf al-Qarḍ̄āwī, Al-Khaṣāiș al-Āmmah li al-Islām, (Bairut : Muassisah arRisālah. 1983), hlm. 131 .

${ }^{9}$ Sesuai dengan yang tertera dalam Peraturan Presiden No. 122 Tahun 2014 juncto Peraturan Menteri Ristek dan Pendidikan Tinggi Nomor 86 Tahun 2017 tentang Statuta UPN Veteran Yogyakarta pasal 3 ayat (3) disebutkan bahwa UPN "Veteran" Yogyakarta merupakan perguruan tinggi yang memiliki ciri khas bela negara.
} 
Oleh karena itu penelitian ini dilakukan dengan tujuan mahasiswa dapat memahami secara mendalam tentang wawasan kebangsaan dan moderasi Islam yang dijabarkan melalui Pendidikan agama Islam serta mata kuliah bela negara dan widya mwat yasa sehingga dapat membentuk jiwa nasionalisme pada mahasiswa di era millenial yang berdasarkan pada nilai-nilai keIslaman. Dan tentunya mahasiswa faham betul mana organisasi-organisasi yang baik baginya yang sesuai dengan ajaran rasul. Dan semua itu memiliki tujuan agar tidak melenceng dari agama, sehingga tidak timbul perpecahan antar agama.

\section{Kerangka Konseptual}

\section{A. Pengertian penguatan wawasan kebangsaan}

Secara etimologis istilah penguatan berasal dari kata "kuat" yang berarti mampu, dalam KBBI dijelaskan bahwa penguatan adalah proses, cara, atau perbuatan menguatkan. ${ }^{10}$ Sedangkan wawasan berarti tinjauan, pandangan atau konsepsi cara pandang, adapun kebangsaan berasal dari kata "bangsa" yang berarti kelompok masyarakat yang bersamaan asal keturunan, adat, bahasa dan sejarahnya serta berpemerintahan sendiri. ${ }^{11}$

Sedangkan menurut terminologi, pengertian wawasan kebangsaan berdasarkan ketetapan MPR tahun 1993 dan 1998 tentang GBHN, wawasan kebangsaan merupakan wawasan nasional yang bersumber pada pancasila dan berdasarkan UUD 1945 adalah cara pandang dan sikap bangsa Indonesia mengenai diri dan lingkungannya dengan mengutamakan persatuan dan kesatuan bangsa.

\footnotetext{
${ }^{10}$ Pusat Bahasa Depdiknas, Kamus Besar Bahasa Indonesia, (Jakarta: Balai Pustaka, 2005), hlm. 102.

${ }^{11}$ M. Quraish Shihab, Wawasan al-quran, tafsir maudhu'i atas berbagai persoalan umat, (Jakarta: Mizan, 1996), hlm. 328.
} 


\section{B. Pengertian moderasi Islam atau wasatiyyah al-Islām}

Dalam KBBI disebutkan moderasi adalah menengahi suatu masalah. Adapun wasațiyyah berasal dari bahasa arab yang berarti adil, utama, pilihan terbaik, dan seimbang antara dua posisi yang berseberangan. Diantaranya kata yang berarti وسوط. المنوسطة و المعتدل

Sedangkan Dr. Abdul Karim az Zaid mendefinisikan wasațiyyah sebagai suatu konsep yang mengandung makna yang luas meliputi karakteristik terpuji (khaṣlah maḥmūdah) di antara dua tercela/ekstrem (țarfāni mażmūmah). ${ }^{13}$

\section{Pengertian Generasi Millenial}

Menurut M. Fadjroel Rachman, generasi millenial adalah aktor signifikan yang menciptakan bonus demografi dan menentukan masa depan Indonesia, khususnya kemajuan ekonomi, sains dan teknologi.

Sedangkan karakter generasi millenial ada tiga yaitu; pertama adalah connected, mereka adalah pribadi yang pandai bersosialisasi dengan berselancar di media sosial dan internet. Kedua adalah creative, mereka adalah orang-orang yang bisa berpikir out of the box, kaya akan ide dan gagasan dan yang ketiga adalah confidence, mereka adalah orang yang sangat percaya diri.

\section{METODOLOGI PENELITIAN}

Dalam sebuah penelitian, metode sangat berperan pada proses sampai hasil penelitian yang dilakukan. penelitian tentang penguatan wawasan kebangsaan dan moderasi Islam ini menggunakan metode kualitatif, yaitu

\footnotetext{
${ }^{12}$ Rāgib al-Aṣfihān,. Mufradāt al-alfāz al-qurān, (Damaskus: Dār al-Qalam, 2009), hlm. 513.

${ }^{13}$ Muhammad Abdul Latif al-Farfur, wasațiyyah al-Islām, (Bairut: Dār al-Nafāis, 1993), hlm. 18.
} 
prosedur penelitian yang menghasilkan data deskriptif berupa kata-kata tertulis atau lisan dari orang-orang dan perilaku yang dapat diamati. ${ }^{14}$

Penelitian ini diperkuat dalam penelitian lapangan (field research) yaitu sebagai metode untuk mengumpulkan data kualitatif dengan cara peneliti berangkat ke lapangan untuk mengadakan pengamatan tentang suatu fenomena dalam suatu keadaan alamiah. Selain itu penelitian ini merupakan studi kasus, yaitu mengumpulkan dan menganalisis data berkenaan dengan suatu kasus. Yaitu bisa berupa masalah, kesulitan, hambatan, penyimpangan atau bahkan keberhasilan dan keunggulan yang terjadi pada perorangan atau kelompok untuk kemudian merumuskan bantuan pemecahannya. ${ }^{15}$ Dengan metode kualitatif dalam bentuk studi kasus, penelitian ini diharapkan dapat menemukan kebenaran dalam bentuk yang semurni-murninya berupa tindakan-tindakan, fenomenafenemona dan gambaran-gambaran mengenai penguatan wawasan kebangsaan dan moderasi Islam. Kemudian, hasil analisis data tersebut disajikan secara deskriptif sehingga dapat memberikan penjelasan secara rinci dan akurat.

Penelitian ini berfokus pada penguatan wawasan kebangsaan dan moderasi Islam bagi generasi millenial, khususnya terkait dengan program-peogram apa saja yang ada di UPN Veteran Yogyakarta, serta bagaimana implementasinya di kampus untuk meningkatkan penguatan wawasan kebangsaan dan moderasi Islam bagi generasi millenial. Selain itu faktor apa saja yang menjadi pendukung dan penghambat dalam proses penguatan wawasan kebangsaan dan moderasi Islam di UPN Veteran Yogyakarta. Dan model-model seperti apa yang penulis

\footnotetext{
${ }^{14}$ Lexy J. Moleong, Metodologi Penelitian Kualitatif, (Bandung: Remaja Rosdakarya, 2012), hlm. 4.

${ }^{15}$ Nana Syaodih Sukmadinata, Metodologi Penelitian Pendidikan, (Bandung: Remaja Rosdakarya, 2004), hlm. 77-78.
} 
tawarkan untuk menambah penguatan wawasan kebangsaan dan moderasi Islam bagi generasi millenial.

Sumber data dalam penelitian ini berupa data-data lapangan terkait penguatan wawasan kebangsaan dan moderasi Islam bagi generasi millenial, yang diperoleh dari data-data hasil observasi lapangan, dokumen-dokumen penelitian dan subyek penelitian atau informan langsung. Teknik pengumpulan data berupa observasi, dokumentasi, dan wawancara. Kemudian dalam menganalisis data menggunakan Triangulasi data dalam hal ini reduksi data, penyajian data dan penarikan kesimpulan. Selanjutnya menggunakan analisis deskriptif analitik, yaitu mendeskripsikan program-program yang sudah disusun oleh pihak kampus untuk memperkuat wawasan kebangsaan dan moderasi Islam bagi generasi millenial.

\section{Hasil dan Pembahasan}

\section{A. Program Wawasan Kebangsaan di UPN Veteran Yogyakarta}

Di UPN Veteran Yogyakarta, program penguatan wawasan kebangsaan diimplementasikan dalam beberapa mata kuliah, diantaranya, bela negara dan widya mwat yasa, pendidikan kewarganegaraan, pancasila, agama Islam, dan olah raga, akan tetapi induk dari semua itu adalah mata kuliah bela negara dan widya mwat yasa. mahasiswa diwajibkan menyanyikan beberapa lagu wajib sebelum memulai pelajaran, diantaranya lagu Indonesia raya, mars bela negara, mars UPN, dan Hymne UPN. Tema-tema yang dipelajari juga sangat erat kaitannya dengan sejarah bangsa Indonesia, cinta tanah air, membela NKRI, kedisiplinan maupun 
kejuangan. ${ }^{16}$ di UPN Veteran Yogyakarta, strategi pembelajarannya sebagai berikut:

1. Proses belajar mengajar di kelas

Dosen bela negara dan Widya Mwat Yasa menerapkan model SCL (Student Center Learning), jadi mahasiswa berperan aktif dalam proses pembelajaran. Proses pembelajaran dengan metode diskusi juga sering dilakukan sesuai dengan tema-tema yang sudah diberikan oleh dosen pengampu. Sedangkan dalam mata kuliah agama Islam menggunakan metode diskusi dan tanya jawab. Tema-tema yang diberikan dalam diskusi sangat update dan menyesuaikan dengan generasi millenial dan juga tema-tema yang sedang dihadapi umat Islam saat ini. Kedisiplinan dan kejuangan juga digalakkan di dua mata kuliah ini.

2. Pembelajaran di luar kelas

Ada beberapa program penunjang untuk penguatan wawasan kebangsaan bagi generasi millenial di luar pembelajaran di kelas untuk mata kuliah bela negara dan widya mwat yasa, diantaranya; Outbond bela negara, outbond ini wajib diikuti oleh semua mahasiswa baru UPN Veteran Yogyakarta. Sedangkan pembelajaran agama di luar kelas adalah program kajian tentang Islam dan perdamaian ini dilakukan khusus dalam satu pertemuan yang membahas tentang esensi Islam yang sesungguhnya, Islam yang rahmatan lil alamin, Islam yang sangat cinta akan perdamaian.

${ }^{16}$ Wawancara dengan Bapak Agus Santoso, SP., M.Si., Dosen Bela Negara dan Widya Mwat Yasa dan observasi peneliti di kelas. 


\section{B. Implementasi Penguatan Wawasan Kebangsaan dan Moderasi} Islam

Implementasi penguatan wawasan kebangsaan tercermin mata kuliah wajib universitas. ${ }^{17}$ Dalam mata kuliah ini memuat unsurunsur bela negara, jadi perpaduan antara materi perkuliahan dengan konsep bela negara. Tidak hanya teori yang didapatkan dari perkuliahan, akan tetapi implementasinya juga didapatkan oleh seluruh mahasiswa UPN Veteran Yogyakarta.

Berikut akan kami ulas terkait implementasi wawasan kebangsaan dan moderasi Islam di UPN Veteran Yogyakarta, diantaranya:

1. Moderat atau tawasut

Tawasut merupakan bagian dari karakter nasionalisme yang konsepnya memiliki kesamaan dengan jujur dan disiplin. Sikap moderat atau tawasut ini terbentuk dalam diri mahasiswa UPN Veteran Yogyakarta.

\section{Toleransi atau Tasāmuh}

Sikap toleransi seringkali dijadikan landasan dan bingkai untuk menghargai perbedaan, tidak memaksakan kehendak dan merasa benar sendiri. Mahasiswa UPN Veteran Yogyakarta memiliki latar belakang yang berbeda-beda, oleh karena itu sikap toleransi ini memang harus benar-benar diterapkan agar kita dapat mengetahui esensi dari menghargai perbedaan.

3. Tawāzun atau keseimbangan

Bagi mahasiswa UPN veteran Yogyakarta, tawāzun diartikan keseimbangan dalam bergaul dan berhubungan, baik yang bersifat

\footnotetext{
${ }^{17}$ Wawancara dengan Bapak Ir. Bambang Wicaksono, M.T., kepala pusat studi Bela Negara UPN Veteran Yogyakarta.
} 
antar individu, antar struktur sosial, antara negara dan rakyatnya, maupun antara manusia dan alam. Setiap hari civitas akademika UPN Veteran Yogyakarta mengenakan seragam ketika di kampus, setiap senin dan selasa menggunakan baju hitam dan bawahan gelap, kemudian setiap hari rabu dan kamis mengenakan batik dan hari jumat menggunakan baju olahraga. Untuk dosen dan tenaga kependidikan pun wajib mengenakan seragam, Hal ini merupakan implementasi sikap tawāzun di UPN Veteran Yogyakarta.

4. Upacara bendera

Tidak hanya mahasiswa, semua civitas akademika UPN Veteran Yogyakarta wajib mengikuti upacara bendera. ${ }^{18}$ Setiap kali ada hari-hari penting dan bersejarah bahkan setiap satu bulan sekali wajib mengikuti upacara. Ini merupakan bentuk implementasi penguatan wawasan kebangsaan.

5. Persiapan kelas

Persiapan kelas ini wajib diterapkan dan dilakukan oleh semua kelas dan semua mata kuliah. Prosesnya dimulai dari persiapan, kemudian berhitung, laporan yang dilakukan oleh ketua kelas kepada dosen pengampu mata kuliah dengan penghormatan kemudian laporan jumlah mahasiswa yang hadir dan berdoa agar diberikan kelancaran dan juga untuk mengenang jasa para pahlawan kita. ${ }^{19}$ Setelah selesai perkuliahan mahasiswa juga wajib melakukan penghormatan dan laporan kepada dosen pengampu. Tujuannya adalah untuk melatih kedisiplinan dan juga menghargai jasa-jasa pahlawan.

18 Wawancara dengan Muhammad Raihan Arfi Zidan, Mahasiswa Fakultas Teknologi Industri.

${ }^{19}$ Hasil observasi peneliti di mata kuliah agama Islam. 


\section{Model Penguatan Wawasan Kebangsaan dan Moderasi Islam}

Setelah memasuki era reformasi atau globalisasi, kehidupan bangsa indonesia dalam bermasyarakat, berbangsa dan bernegara dalam bingkai paham nasionalisme terasa semakin kehilangan arahnya, dalam hubungannya dengan upaya mencapai cita-cita nasional, yaitu melindungi, mensejahterakan, mencerdaskan dan ikut menertibkan dunia seperti diamanatkan dalam pembukaan UUD 1945. Ironisnya kondisi yang dirasakan yaitu "kehilangan arah tersebut".

Politik identitas sebagai jawaban terhadap globalisasi dengan kemajuan teknologi, terutama teknologi informasi yang telah menghilangkan sekat identitas kelompok, baik berdasarkan ras, agama, etnis, budaya atau ciri primodialisme lainnya. Keinginan kelompok-kelompok tersebut untuk tetap eksis secara politik, ekonomi, maupun budaya pada gilirannya telah memunculkan politik identitas. Kemunculan politik identitas di Indonesia kenyataannya telah didominasi oleh warna agama. Perkembangan politik identitas ini sangat tidak sehat, rawan, berbahaya dan menjadi ancaman bagi pancasila, keutuhan bangsa dan kelangsungan negara. Bagaimana negara ini bisa tetap bisa bersatu jika selalu terjadi perselisihan dan perbedaan, padahal setiap warga negara wajib menjaga melindungi serta membela kesatuan dan keutuhan NKRI, bukan malah saling bersaing satu sama lain.

Sebagaimana termaktub dalam konstitusi terkait kewajiban bela negara yakni Pasal 27 ayat (3) dan Pasal 30 ayat (1) UUD NKRI Tahun 1945. Turunan daripada konstitusi tersebut, diatur lebih lanjut dalam Undang-Undang Nomor 3 Tahun 2002 tentang Pertahanan 
Negara (UUD:2015). Undang-undang tersebut semakin menguatkan kewajiban bela negara bagi tiap waga negara, sebagaimana dimaksud dalam pasal 9 ayat (1) undang-undang a quo. Penjelasan pasal tersebut mendefinisikan bela negara sebagai sikap dan perilaku negara yang dijiwai oleh kecintaannya kepada Negara Kesatuan Republik Indonesia yang berdasarkan Pancasila dan Undang-Undang Dasar 1945 dalam menjamin kelangsungan hidup bangsa dan negara. Selanjutnya, Pasal 9 ayat (2) undang-undang a quo mengatur bahwa keikutsertaan warga negara dalam upaya bela negara diselenggarakan melalui: Pendidikan kewarganegaraan; Pelatihan dasar kemiliteran secara wajib; Pengabdian sebagai prajurit Tentara Nasional Indonesia secara sukarela atau secara wajib; dan Pengabdian atau secara profesi.

Dari penjelasan di atas dapat kita simpulkan bahwa bela negara merupakan hak sekaligus kewajiban bagi setiap warga negara, tak terkecuali warga negara Indonesia, karena ini merupakan hal yang sangat penting agar dapat terciptanya kehidupan bermasyarakat yang tertib, aman, damai, serta untuk menjaga dan memelihara kedaulatan NKRI.

Di antara nilai-nilai bela negara yang pertama adalah cinta tanah air; dalam hal ini tidak cukup hanya dengan mencintai akan tetapi rakyat atau bangsa Indonesia harus menjaga tanah, pekarangan, maupun seluruh wilayah Indonesia, selain itu sebagai bangsa Indonesia kita harus memiliki rasa bangga sebagai bangsa Indonesia, salah satunya dengan cara belajar dan berusaha berkorban demi negara Indonesia serta mengaplikasan wawasan kebangsaan dan moderasi Islam, lain dari pada itu sebagai generasi millenial 
mencintai tanah air bisa dengan memberikan kontribusi kepada NKRI, dengan capaian prestasi-prestasi yang luar biasa.

Kedua, kesadaran berbangsa dan bernegara, dalam hal ini sebagai bangsa Indonesia kita harus berpartisipasi aktif dalam berbagai organisasi-organisasi yang positif serta aktif dalam menjaga kedaulatan bangsa dan negara. tanpa memiliki rasa kesadaran yang cukup tinggi, para generasi millenial tidak akan memiliki kemauan untuk membela dan mempertahankan NKRI.

Ketiga, yakin pada pancasila sebagai ideologi negara, hal ini bisa diaplikasikan dengan memahami dan mengamalkan nilai-nilai pancasila serta menjadikan pancasila sebagai alat pemersatu bangsa, bukan malah menjadikan pancasila sebagai alat untuk saling bermusuhan antar sesama bangsa Indonesia.

Keempat, rela berkorban demi bangsa dan negara, hal ini bisa dibuktikan dengan lebih mementingkan kepentingan umum dari pada kepentingan pribadi, serta mencurahkan segala perhatian, pikiran untuk kepentingan negara Indonesia tanpa mengharapkan imbalan apapun, murni untuk mengabdi kepada NKRI termasuk rela mengorbankan waktu, jiwa, dan raganya demi kepentingan bangsa dan negara tercinta.

Kelima, memiliki kemampuan awal bela negara baik fisik maupun psikis, dalam hal ini generasi muda dan seluruh bangsa Indonesia harus memiliki kecerdasan emosional, spiritual dan intelegensia, agar bisa mengontrol segala jiwa dan raganya agar memiliki kemampuan yang cukup untuk berjuang dan menjaga NKRI, dan juga selalu bersyukur dan berolah raga, agar memiliki jiwa dan raga yang kuat. 
Sesuai dengan nilai-nilai bela negara di atas, para generasi muda khususnya harus berjuang dan berkorban demi kepentingan bangsa dan negara, oleh karena itu mereka para generasi millenial harus dibekali dengan pengetahuan-pengetahuan yang cukup agar mampu memahami dan mengimplementasikan nilai-nilai bela negara dalam kondisi apapun dan kapanpun. Karerna generasi millenial adalah generasi yang serba instan, semua bisa didapatkan dengan sangat mudah dan ekspres. Keseharian mereka selalu dimonopoli oleh media sosial dan juga smart phone. Oleh karena itu harus selalu mengingatkan kepada mereka untuk tetap sadar bahwa mereka berbangsa Indonesia sehingga budaya apa saja dari luar yang sudah berkembang, harapannya bisa kita imbangi dengan mengingatkan kecintaan mereka terhadap bangsa dan tanah air indonesia, baik dari aspek ideologi, politik, sosial, ekonomi, maupun pertahanan dan keamanan.

Harapannya diadakan pembekalan khusus untuk generasi millenial yang sudah terdegradasi oleh pengaruh media sosial ini sehingga mata dan telinga mereka terlupakan oleh aktivitas yang jauh dari nilai kebangsaan. Kunjungan-kunjungan ke museum dan pelatihan yang berkaitan dengan ketentaraan wajib ditingkatkan agar mereka bisa memahami lebih jauh terkait makna konsep wawasan kebangsaan yang sesungguhnya.

Setidaknya ada empat persoalan mendasar mengapa bela negara ini perlu diintegrasikan di setiap perguruan tinggi, bahkan perguruan tinggi perlu menjadikan bela negara sebagai perhatian yang cukup serius. Pertama adalah kita tidak bisa membantah dari hasil penelitian yang dilakukan oleh Lembaga Survei Indonesia Denny Januar Ali (LSI Denny JA) tentang menurunnya jumlah orang-orang 
yang pro terhadap pancasila dan naiknya orang-orang yang pro terhadap NKRI bersyariah. ${ }^{20}$

Menurut hasil riset LSI Denny JA, ada penurunan kurang lebih sekitar 10\% dalam kurun waktu 15 tahun. Yang semula Pada tahun 2005 berjumlah 85,2\% dan di tahun 2018 berjumlah $75.3 \%$ sedangkan NKRI bersyariah naik sekitar 9\%. Kedua adalah nilai etis yang kian menurun. Kita juga tidak bisa membantah di era media sosial hoax semakin meninggi dan manusia terbiasa saling menghujat satu sama lain, tawuran antar remaja bahkan narkoba semakin merajalela. ${ }^{21}$ Dan yang ketiga adalah maraknya radikalisme dan disintegrasi. Kita juga tidak bisa membantah bahwa keterlibatan anak-anak muda mulai dari level SMA sampai perguruan tinggi banyak terlibat pada paham dan gerakan radikalisme. Yang keempat adalah soal kompetensi bangsa, kita dituntut untuk meningkatkan kompetensi bangsa, kompetensi rakyat Indonesia agar bisa bersaing dengan negara-negara lain, namun faktanya, menurut hasil riset anakanak muda Indonesia baru siap menghadapi keterampilan abad 21pada abad $31 .^{22}$ Ini artinya Indonesia tertinggal 100 tahun dibandingkan negara-negara lain.

Oleh karena itu kita tidak bisa membantah temuan-temuan tersebut, hanya kita perlu sadari yang terpenting adalah bagaimana kita melakukan itu semuanya, melakukan langkah-langkah kecil untuk memperbaiki keempat persoalan-persoalan bangsa ini.

${ }^{20}$ Sakina Rakhma. https://nasional.kompas.com/read/2018/07/17/15580981/surveidalam-13-tahun -persentase publik-pro-pancasila-terus-menurun.

${ }^{21}$ Herdina Indrijatai, Hubungan antara Kecerdasan Emosi dengan Perilaku Tawuran pada Remaja Laki-laki yang Pernah Terlibat Tawuran di SMK 'B' Jakarta. Jurnal Psikologi Pendidikan dan Perkembangan Vol. 3 No.01, 2014.

${ }^{22}$ Amanda Beatty dkk, 15 years of education in Indonesia: rising enrolment and flat learning profil. CFFE annual Research Digest, 2016, hlm. 5. 
kemudian bagaimana kiranya bela negara ini dapat diintegrasikan diperguruan tinggi, apa saja model-model penguatan wawasan kebangsaan dan moderasi Islam di masa depan yang bisa diimplementasikan di semua perguruan tinggi di Indonesia.

Pertama adalah mandiri otonomi dalam pengertian bahwa program ini berdiri sendiri terpisah dari program-program lain, ia memiliki program yang terstruktur dan sistematis. Tidak terintegrasi ke dalam kurikulum yang ada dan tidak juga tercover ke dalam program-program kemahasiswaan ataupun program-program akademik dan non akademik di perguruan tinggi. Tetapi murni menjadi sebuah kajian yang terstruktur, sistematis akan tetapi terpisah dari ekosistem Perguruan Tinggi Pada umumnya.

Kedua adalah embedded-partial artinya ini mengandaikan adanya penguatan Mata kuliah umum terutama Mata Kuliah Dasar Umum (MKDU), dengan memasukkan nilai-nilai bela negara, seperti pancasila, kewarganegaraan, bahasa Indonesia, olahraga, dan pendidikan agama. Kemudian bagaimana nilai-nilai bela negara itu dimasukkan ke mata kuliah tersebut, selain pada mata kuliah wajib nilai-nilai bela negara juga bisa dimasukkan ke dalam kegiatan kemahasiswaan tetapi ini masih belum terintegrasi ke dalam seluruh mata kuliah. Hanya sebatas mata kuliah wajib universitas saja. Karena ketika kita mengintegrasikan secara keseluruhan ekosistem pendidikan dalam Perguruan tinggi maka itu masuk ke dalam level ketiga.

Ketiga, yaitu integrasi. Dalam model ini bela negara bukan hanya menjadi kewenangan dari MKDU tetapi keseluruhan mata pelajaran yang ada mulai menyusun dari kurikulum, Student Learning Outcomes, Program Learning Outcames, kemudian disusun 
bagaimana aspek-aspek bela negara masuk ke dalam kurikulum, non kurikulum, kemahasiswaan dan pengajaran. Tetapi ketiga model ini tetap mengandalkan adanya pusat studi bela negara yang memang spesifik fokus untuk berbicara, meneliti dan melaksanakan program bela negara. Sehingga program ini bisa berjalan dengan baik.

\section{Implementasi Model Penguatan Wawasan Kebangsaan dan Moderasi Islam Bagi Masa Depan}

Setelah peneliti menawarkan ketiga program di atas, berikut akan peneliti deskripsikan bagaimana proses Implementasinya agar bisa terlaksana dengan baik. Dari ketiga program yang peneliti paparkan di atas, implementasi terwujud dalam lima hal:

1. Tri dharma perguruan tinggi

Tri Dharma Perguruan Tinggi merupakan tiga hal yang harus dimiliki dan harus ada di sebuah perguruan tinggi saat aktivitas akademik berlangsung. Dan tiga hal tersebut merupakan kewajiban yang harus dilaksanakan dan dikembangkan secara berkesinambungan oleh seluruh civitas akademika, di antaranya dosen dan mahasiswa. Idealnya Tri Dharma Perguruan Tinggi ini terinternalisasi ke dalam jiwa seluruh civitas akademika, sehingga istilah ini bukan hanya slogan atau jargon belaka. Namun hal inipun menjadi budaya yang disadari oleh semuanya. Dengan begitu, maka cita-cita dari Tri Dharma Perguruan Tinggi ini akan terwujud dan terimplementasikan dengan baik.

Dalam hal ini nilai-nilai bela negara diintegrasikan ke dalam tri dharma, baik pengajaran, penelitian, maupun pengabdian masyarakat. Di sela-sela melakukan tri dharma perguruan tinggi, dosen maupun mahasiswa harus selalu menanamkan nilai-nilai bela negara. 
2. Budaya

Ketika kita ingin menerapkan nilai-nilai bela negara, salah satu hal yang harus kita lakukan adalah pembiasaan dalam kehidupan keseharian, khusunya keseharian di perguruan tinggi. Sebagaimana yang kita ketahui bahwa sebagai sebuah nilai-nilai bela negara tidak akan bermakna apa-apa tanpa adanya proses pembudayaan di kalangan masyarakat, khususnya masyarakat kampus. Dengan melakukan pembiasaan menanamkan nilai-nilai bela negara dalam kehidupan sehari-hari, dengan sendirinya akan terbentuk jiwa-jiwa bela negara tanpa adanya paksaan, karena hal tersebut sudah melekat pada individu masing-masing.

3. Kemahasiswaan

Bela negara juga bisa terintegrasi dalam kegiatan Badan Eksekutif Mahasiswa (BEM), Unit Kegiatan Mahasiswa (UKM), seperti resimen mahasiswa atau pramuka, sehingga bela negara dijiwai secara betul oleh mahasiswa. Dan dalam keseharian bukan hanya mahasiswa dapat mewujudkan, mengejawantahkan nilainilai bela negara dalam kehidupan sehari-sehari, sebagai mahasiswa, sebagai individu, sebagai warga negara, anak, dan sebagai bagian dari masyarakat, bahkan warga negara dunia.

4. Kegiatan akademik

Dalam hal ini bela negara terintegrasi ke dalam kegiatan akademik, seperti mata kuliah. Strateginya adalah paling tidak dalam perguruan tinggi ada tiga hal. Pertama adalah pembelajaran. Hendaknya kita menyusun silabus, sebagaimana membayangkan integrasi pendidikan karakter di perguruan tinggi. Karena ada beberapa nilai yang sama antara keduanya, seperti nasionalisme misalnya. Dan yang menjadi perbedaan adalah 
fokusnya: pendidikan karakter lebih berorientasi pada diri seorang mahasiswa, sementara bela negara lebih pada bagaimana mahasiswa memberikan sesuatu kepada negara. strateginya adalah melalui pembelajaran, ekstra kulikuler dan pengembangan budaya perguruan tinggi.

Melalui model implementasi dalam perguruan tinggi, misalkan memilih atau menggunakan model pertama, kedua, maupun ketiga itu bisa dilakukan melalui penguatan mata kuliah MKDU atau integrasi secara umum, yang kedua melalui kegiatan ekstra kulikuler BEM maupun UKM. Kemudian selain itu, berdasarkan hasil observasi lapangan, antara kedua UPN Veteran, yaitu Jawa Timur dan Yogyakarta, kampus bela negara ini telah memberikan banyak contoh tentang bagaimana bela negara ini bisa dilakukan tentu ada banyak hal yg bisa dikembangkan lebih jauh oleh UPN sebagai best mark kampus yang menerapkan filosofi dan nilai-nilai bela negara.

\section{Penutup}

Berdasarkan keseluruhan uraian dan analisis tentang hasil riset tentang "Penguatan Wawasan Kebangsaan dan Moderasi Islam Untuk Generasi Millenial, peneliti dapat mengambil kesimpulan bahwa Program-program tentang wawasan kebangsaan dan moderasi Islam di UPN Veteran Yogyakarta diimplementasikan dalam beberapa mata kuliah, diantaranya, bela negara dan widya mwat yasa, pendidikan kewarganegaraan, pancasila, agama Islam, dan olah raga, akan tetapi induk dari semua itu adalah mata kuliah bela negara dan widya mwat yasa. Selain itu program-program penunjang lainnya seperti pembelajaran di dalam kelas maupun di luar kelas. 
Program pembelajaran di dalam kelas diantaranya melalui metode diskusi, ceramah, membaca al-qur'an, kajian-kajian keislaman, kemudian review jurnal terkait dengan tema-tema terkini yang sudah sesuai dengan silabus dan bahan ajar lainnya yang sudah diberikan oleh dosen pengampu mata kuliah. Sehingga mahasiswa selalu update dengan tematema terbaru. Program ini dilakukan untuk menambah pengetahuan mahasiswa terkait dengan wawasan kebangsaan dan moderasi Islam di era millenial ini.

Sedangkan program pembelajaran di luar kelas ini dikaitkan dengan pemberdayaan dan pengabdian kepada masyarakat, bagaimana implementasi materi-materi yang sudah didapatkan di dalam kelas kemudian diterapkan di lingkungan masyarakat. Hal ini bisa berupa kegiatan-kegiatan sosial seperti membersihkan masjid, donasi, memberikan ceramah keagamaan di masyarakat setempat atau sekedar berdiskusi dengan kelompok masyarakat di sekitarnya atau mahasiswa sesama muslim.

Diskusi ini bertujuan agar mahasiswa mampu mengetahui keadaan masyarakat di luar tentang bagaimana pemahaman warga terkait moderasi Islam dan pengaplikasiannya. Sehingga teori yang sudah diajarkan di kelas bisa langsung dipraktekkan dalam kehidupan seharihari dan tentunya memberikan manfaat kepada sesama. Kemudian terkait dengan wawasan kebangsaan mahasiswa wajib mengikuti outbond bela negara yang harus diikuti oleh semua mahasiswa baru UPN Veteran Yogyakarta. dari outbond ini mereka bisa belajar banyak hal terkait dengan kebersamaan, kedisiplinan, kekompakan, serta mengaktualisasikan nilai-nilai bela negara dalam kehidupan sehari-hari. 


\section{DAFTAR PUSTAKA}

\section{Buku}

Creswell, John W, Research Design: Pendekatan Kualitatif, Kuantitatif dan mixed, Yogyakarta: Pustaka Pelajar, 2007.

Djamarah, Bahri, Syaiful Zain \& Aswan, Strategi Belajar Mengajar, Jakarta: Rineka Cipta, 2002.

Emzir, Analisis Data: Analisis Metodologi Penelitian Kualitatif, Jakarta: Rajawali Press, 2012.

Forum Intelektual Indonesia, Jati Diri Bangsa dalam Ancaman Globalisasi, Jakarta: Airlangga University Press, 2007.

Kardi, S., Pengajaran Langsung, Surabaya: Unesa University Press, 1997.

Kristyanti, J. Rosalina dkk, Peluang dan Tantangan Pendidikan Abad 21, Jakarta: Sampoerna University, 2012.

Moleong, Lexy J, Metodologi Penelitian Kualitatif, Bandung: PT. Remaja Rosdakarya, 2012.

Sebastian Yoris dan Amran Dilla, Generasi Langgas Millenials Indonesia, Jakarta: Gagas Media, 2016.

\section{Jurnal}

Hambali. (2015). Students Reaction Towards Nation Characters Education and the Impacts on The Practice of Nationalist Characters. Journal of Applied Sciences. 15 (9). ISSN 1812-5654 Asian Network for Scientific Information. Indrijatai, Herdina. (2014). Hubungan antara Kecerdasan Emosi dengan Perilaku Tawuran pada Remaja Laki-laki yang Pernah Terlibat Tawuran di SMK 'B' Jakarta. Jurnal Psikologi Pendidikan dan Perkembangan Vol. 3 No.01.

Iswanto. Agus. (2018). Membaca Kecenderungan Pemikiran Islam Generasi Millenial Indonesia. Jurnal Multikultural dan Multireligius Vol. 17. No. 1. Juni 2018.

Partini. (2012). National Character Building in the Third Millenium Era: A Challenge. Southeast Asian Journal of Social and Political Issues. Vol. 1. No. 2. Maret 2012.

Rifa'i, Anwar. (2017). Jurnal Vol. 6. No. 1 "Pembentukan Karakter Nasionalisme melalui Pembelajaran Pendidikan Aswaja pada Siswa Madrasah Aliyah Al Asror Semarang”.

Widiatmaka, Pipit. (2016). Jurnal pendidikan dan kewarganegaraan Vol. 1 No.1 "Pembangunan Karakter Nasionalisme Peserta Didik di Sekolah Berbasis Agama Islam". 